\title{
Characterization of Cassava Root Husk Powder: Equilibrium, Kinetic and Modeling Studies as Bioadsorbent for Copper(II) and Lead(II)
}

\author{
Kaupa Philip ${ }^{1}$, Rebecca Jacob ${ }^{2}$, Janarthanan Gopalakrishnan ${ }^{1}$ \\ ${ }^{1}$ Department of Applied Sciences, PNG University of Technology, Lae, Papua New Guinea \\ ${ }^{2}$ School of Chemistry, University of Sydney, Sydney, Australia \\ Email: ^philip.kaupa@pnguot.ac.pg, rebecca.jacob@sydney.edu.au
}

How to cite this paper: Philip, K., Jacob, R. and Gopalakrishnan, J. (2021) Characterization of Cassava Root Husk Powder: Equilibrium, Kinetic and Modeling Studies as Bioadsorbent for Copper(II) and Lead(II). Journal of Encapsulation and Adsorption Sciences, 11, 69-86.

https://doi.org/10.4236/jeas.2021.112004

Received: February 25, 2021

Accepted: June 5, 2021

Published: June 8, 2021

Copyright $\odot 2021$ by author(s) and Scientific Research Publishing Inc. This work is licensed under the Creative Commons Attribution International License (CC BY 4.0).

http://creativecommons.org/licenses/by/4.0/

\begin{abstract}
This study was aimed to investigate $\mathrm{Pb}$ (II) and $\mathrm{Cu}(\mathrm{II})$ ions removal ability from aqueous solution by cassava root husks (CRH) as a cheap, sustainable and eco-friendly bioadsorbent. The $\mathrm{CRH}$ was characterized by Fourier Transform Infrared (FTIR) spectroscopy which indicated the availability of various functional groups for metal coordination and the result was supported by elemental analysis studies. UV-Visible spectral studies indicated the presence of oxalate $\left(\mathrm{C}_{2} \mathrm{O}_{4}^{2-}\right)$ and it could possibly interact with metal ions to give rise to a stable chelated coordination complex which affects metal ions removal efficiency. Bioadsorption process was carried out as a function of metal concentration, contact time, $\mathrm{pH}$ of the solution, particle size, and dosage of the adsorbent. Experimental results indicated the optimal adsorption condition of $\mathrm{pH} 4$ for both $\mathrm{Pb}(\mathrm{II})$ and $\mathrm{Cu}(\mathrm{II})$ ions, dosage of $0.1 \mathrm{~g} / 0.1 \mathrm{~L}$ and 1 $\mathrm{g} / 0.1 \mathrm{~L}$ for $\mathrm{Pb}(\mathrm{II})$ and $\mathrm{Cu}(\mathrm{II})$ ions respectively, adsorption equilibrium time of 2 and 25 minutes for $\mathrm{Pb}(\mathrm{II})$ and $\mathrm{Cu}(\mathrm{II})$ respectively, and concentration of 0.5 $\mathrm{mg} / \mathrm{L}$ for both metal ions. Kinetic data best fitted pseudo-second-order model and not the pseudo-first-order model. Equilibrium data best fitted the Freundlich model than the Langmuir model. Specific surface area and pore volume studies indicated that $\mathrm{CRH}$ is non-porous and hence rapid adsorption kinetics is expected. Supporting the experimental results, molecular modeling studies performed using Schrödinger software predicted several sites in the structure capable of docking with metal ions.
\end{abstract}

\section{Keywords}

Bioadsorption, Langmuir Isotherm, Freundlich Isotherm, Pseudo-First-Order Kinetics, Pseudo-Second-Order Kinetics, Cassava Root Husk, Molecular Modeling 


\section{Introduction}

Among water pollutants, synthetic dyes and heavy metals pose severe health threats and the latter is currently a concern in many parts of Papua New Guinea (PNG) especially in urban and mining areas [1] [2]. Many reviews are dedicated to identifying and presenting low-cost sorbents for heavy metal removal and recovery [3] [4]. Therefore it is important to find an economically viable treatment method for drinking water as well as wastewater to minimize the concentrations of heavy metals in water bodies. The objective of this research was to investigate the effectiveness of the root husk of cassava (Manhiot esculenta) to remove $\mathrm{Pb}$ (II) and $\mathrm{Cu}$ (II) ions from solutions through the process of bioadsorption. Among several techniques, adsorption using solid materials, such as modified silica, alumina, activated carbon, and resin, is considered as the superior methods for metal ion extraction process [5] [6] [7]. However, these materials are expensive to acquire in many developing countries [8] including PNG. According to McKay [6], the criteria for adsorption as an efficient treatment process is to first search for an adsorbent with high selectivity, high adsorbent capacity, abundant availability at low cost. Bioadsorption using agricultural wastes have the advantage of being readily available in tones and can bind metals through various mechanisms such as chelation/coordination, ion exchange, precipitation, and sorption by other physical and chemical forces [9]. Cassava is a common food crop in many countries around the world and managing and dumping of their root husks become a burden so they can be utilized effectively for purifying water as well as for trapping valuable metals.

FTIR is an important tool used in identifying the functional groups available on biomaterials which are responsible for the heavy metal ions coordination. FTIR uses an interferometer and flourier transformations to obtain a spectrum corresponding to wave numbers that can be assigned to certain functional groups of a biomaterial. Elemental analysis (CHNS) was used to determine the percentage elemental composition of carbon, hydrogen, nitrogen, and sulphur. This provides the basis for identifying the species of elements that can either act as Lewis base and anions for metal sequestration. Bioadsorption studies are usually carried out in batch processes as a function of experimental perimeters such as $\mathrm{pH}$, dosage, contact time, concentration, and agitation speed. The data from concentration and contact time are used to generate the equilibrium and kinetic data respectively. Data from equilibrium and kinetic studies are related to the $\mathrm{CRH}$ characterization studies to explain in detail the metal ion adsorption mechanism. Computational studies were done to further explain the interaction between the metal ions and the $\mathrm{CRH}$ with Schrodinger software, by carrying out docking studies using Glide. Schrodinger is a suite of molecular modeling packages that take advantage of the latest technological advances in computational chemistry [10]. Additionally, $\mathrm{pH}$ studies were also carried out to account for the adsorption behaviors.

Equilibrium studies provide data on the capacity (or affinity) of the adsorbent 
for the solute and hence the dosage of absorbent required to remove a unit mass of solute from the solution. Mathematically equilibrium is expressed in isotherms. Two commonly used isotherms are Langmuir and Freundlich [11] [12] [13] and their applicability is judged with correlation coefficient $\left(R^{2}\right)$. The Langmuir isotherm assumes mono-layer adsorption on a uniform surface with a finite number of adsorption sites and maximum adsorption occurs when a saturated mono-layer of adsorbate is present on the adsorbent surface [5] [6]. The linear form of Langmuir isotherm model [14] is given in Equation (1). Here, $K_{a d s}$ is the equilibrium constant that increases with increasing molecular size (Langmuir constant), $q_{\max }$ is the adsorption capacity $(\mathrm{mg} / \mathrm{g}), q_{e}$ is the equilibrium adsorption $(\mathrm{mg} / \mathrm{g})$ and $C_{e}$ is the equilibrium (residual) concentration of metal ion $(\mathrm{mg} / \mathrm{L})$.

$$
\frac{C_{e}}{q_{e}}=\frac{1}{K_{a d s} q_{\max }}+\frac{C_{e}}{q_{\max }}
$$

The dimensionless separation factor $R_{L}$ is given in Equation (2) which is an essential feature of Langmuir isotherm [15]. If $R_{L}=0$, the process is said to be irreversible, if $R_{L}=1$, it is linear, if $R_{L}>1$, it implies an unfavourable adsorption and if $0<R_{L}<1$, it's a favourable adsorption. $C_{i}$ is the initial concentration of metal ions $(\mathrm{mg} / \mathrm{L})$.

$$
R_{L}=\frac{1}{1+K_{a d s} C_{i}}
$$

Freundlich isotherm is an empirical model and describes equilibrium on heterogeneous surface and does not assume mono-layer adsorption. It is an indicator of the extent of heterogeneity of adsorbent surface [6]. The linear form of Freundlich isotherm [14] is represented in Equation (3), where $K$ is Freundlich constant or adsorption capacity and $1 / n$ is adsorption intensity.

$$
\log q_{e}=\log K+\frac{1}{n} \log C_{e}
$$

Adsorption kinetics describes the adsorption mechanism as well as estimates the time required for obtaining equilibrium concentration of metal ions onto the biomass [6]. It measures the efficiency of the process and shows a large dependence on physical and/or chemical characteristics of the sorbent material [15]. Commonly used are pseudo-first-order and pseudo-second-order models and their linear forms are given in Equations (4) and (5) respectively [15].

$$
\begin{gathered}
\log \left(q_{e}-q_{t}\right)=\log q_{e}-\left(\frac{k_{1}}{2.303}\right) t \\
\frac{t}{q_{t}}=\frac{1}{k_{2} q_{e}^{2}}+\left(\frac{1}{q_{e}}\right) t
\end{gathered}
$$

Here $q_{t}$ is the adsorption capacity at time $t(\mathrm{mg} / \mathrm{g})$ and $k_{1}$ is the rate constant of pseudo-first-order $\left(\mathrm{min}^{-1}\right)$ and $k_{2}$ is the rate constant of pseudo-second-order $\left(\mathrm{g} \cdot \mathrm{mg}^{-1} \cdot \mathrm{min}^{-1}\right)$. 


\section{Materials and Methods}

\subsection{Materials}

All the chemicals used in this study were analytical grade: $\mathrm{CuSO}_{4} \cdot 5 \mathrm{H}_{2} \mathrm{O}(98 \%)$, $\mathrm{Pb}\left(\mathrm{NO}_{3}\right)_{2}$ (99\%), $\mathrm{H}_{2} \mathrm{SO}_{4}$ (95\%), $\mathrm{NaOH}$ (97\%), (Ajax Fine Chem, Australia).

\subsection{Preparation and Characterization of $\mathrm{CRH}$ of Bioadsorbent}

Cassava samples were harvested from Markham, Morobe Province, PNG $\left(-6^{\circ} 38^{\prime} 29.51^{\prime \prime S}\right.$ and $\left.146^{\circ} 51^{\prime} 37.55^{\prime \prime} \mathrm{E}\right)$. The $\mathrm{CRH}$ were peeled from the pulp, cleaned and washed thoroughly with tap water and rinsed with distilled water. The CRH were then cut into smaller pieces, sun dried for 7 days and then ground and sieved to get particle sizes $\leq 50 \mu \mathrm{m}$. A summary schematic representation of the process is depicted in Figure 1.

CRH powder was characterized using FTIR (using JASCO FT/IR-4100 spectrometer, recorded as $\mathrm{KBr}$ pellet), $\mathrm{CHN}$ analysis (using PerkinElmer 2400 Series CHNS/O Analyzer), specific surface area and pore size volume (using Micromeritics ASAP 2020 surface area and porosimetry system) measured at Dept. of Chemistry, IIT Madras, India. The sample for specific surface area and pore size volume determinations was outgassed at $100^{\circ} \mathrm{C}$ for 12 hour and the parameters were obtained using nitrogen adsorption BET isotherms. The equilibrium interval during the measurement was maintained for $5 \mathrm{sec}$. UV-Visible spectrum (using Varian 50 Bio UV-Vis spectrophotometer, recorded as a clear solution (1 $\mathrm{g}$ of powder was mechanically shaken with $100 \mathrm{~mL}$ of distilled water for $1 \mathrm{~h}$ and filtered)) and $\mathrm{pH}$ (using TPS Labchem $\mathrm{pH}$ meter at $28^{\circ} \mathrm{C} \pm 0.5^{\circ} \mathrm{C}$ ) were measured at Dept. of Applied Sciences, Papua New Guinea University of Technology (PNGUoT), PNG. Sulphur as sulphate, phosphorus as phosphate and metal ion concentrations were determined by ICP-OES using Varian 725-ES ICP-OES at UASL, Dept. of Agriculture, PNGUoT, PNG.
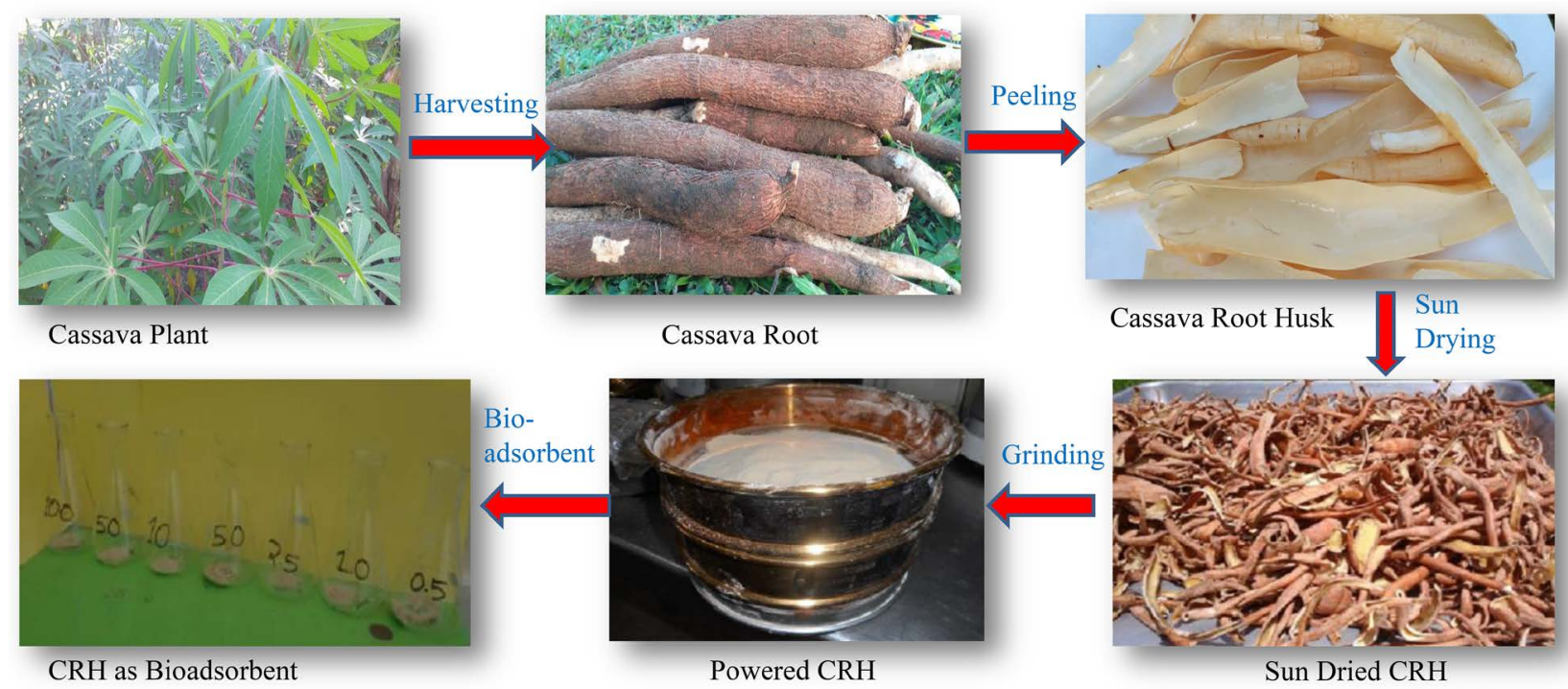

Figure 1. Preparation of CRH as bioadsorbent for the study. 


\subsection{Bioadsorption Experiment}

Stock solutions $(1000 \mathrm{mg} / \mathrm{L})$ of metal ions were prepared by dissolving $3.92 \mathrm{~g}$ and $1.59 \mathrm{~g}$ of $\mathrm{CuSO}_{4} \cdot 5 \mathrm{H}_{2} \mathrm{O}$ and $\mathrm{Pb}\left(\mathrm{NO}_{3}\right)_{2}$ respectively in distilled water. These solutions were diluted to various concentrations and were used in the experiments. The bioadsorption studies were carried out with the desired mass of the bioadsorbents placed in $100 \mathrm{~mL}$ of metal ion solution with desired concentration and $\mathrm{pH}$ in $250 \mathrm{~mL}$ conical flasks. The flask is then shaken with a mechanical flask shaker at $240 \mathrm{rpm}$ at room temperature for the desired time. Buchner funnel with Whatman No.1 filter paper was used to filter the bioadsorbent with adsorbed metal and the filtrate was analyzed for residual metal ion concentration using inductively coupled plasma-optical emission spectroscopy (ICP-OES). The effect of the solution $\mathrm{pH}$ was investigated in the range of $1-12$ with addition of $0.1 / 1 \mathrm{M} \mathrm{NaOH}$ and $\mathrm{H}_{2} \mathrm{SO}_{4}$. Filtrates were collected at time ranging from 0.5 to 100 minutes to study the effect of the contact time. The effect of concentration was investigated with metal ion concentration ranging from 0.5 to $100 \mathrm{mg} / \mathrm{L}$. Bioadsorbents dosage ranging from 0.05 to $10 \mathrm{~g}$ were used to investigate the effect of dosage.

\section{Result and Discussion}

\subsection{Characterization of CRH}

\subsubsection{Infrared Spectral Studies}

The FTIR spectra of CRH are provided in Figure 2. The presence of hydroxyl and carboxylic acid groups, methionine, and tryptophan, aromatic molecules such as thiamine and other amino acids [16] [17] make the band assignments quite complex and an attempt was made to assign the observed bands (Table 1)

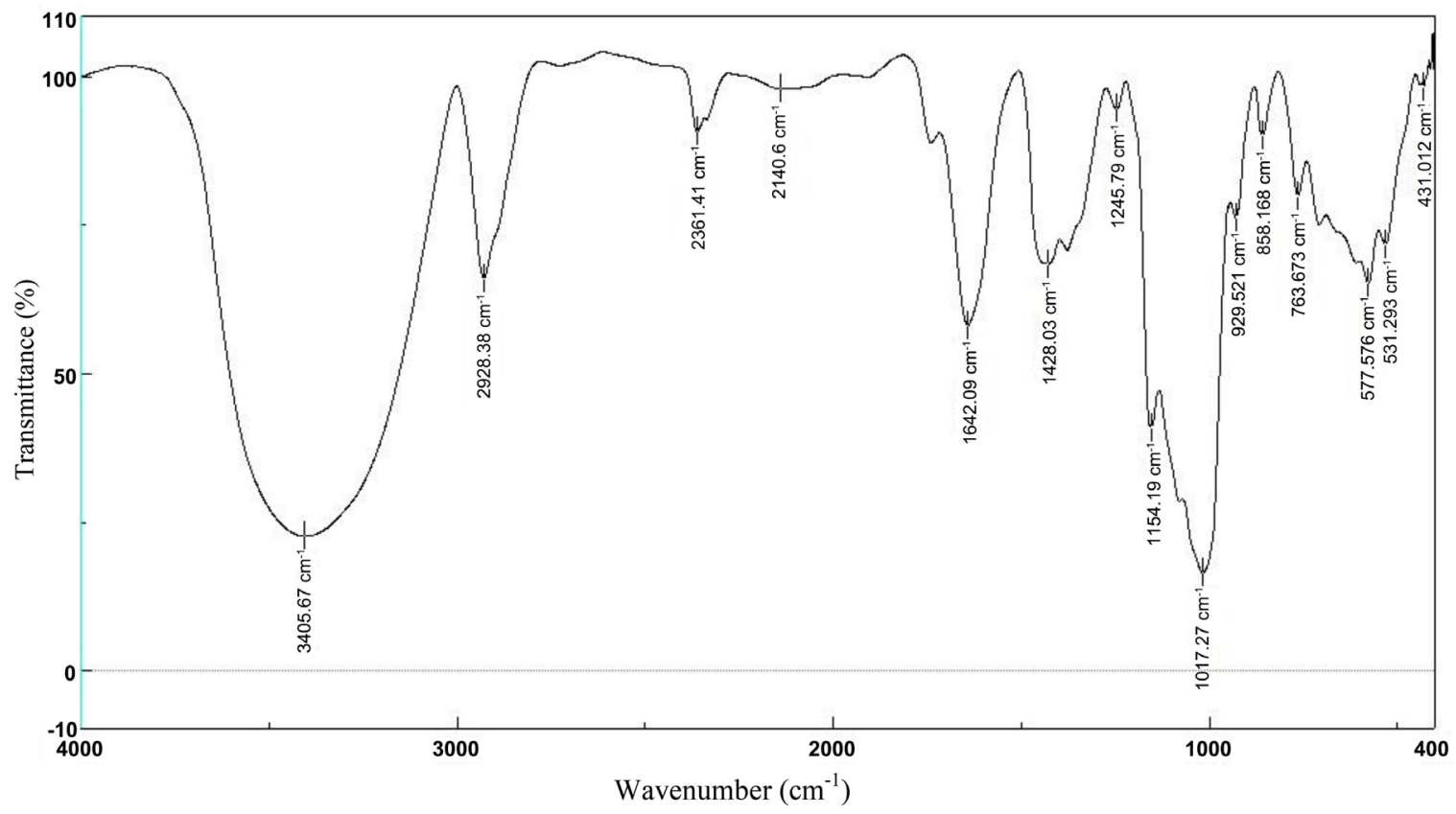

Figure 2. FTIR spectrum of CRH powder. 
Table 1. Infrared spectral data for $\mathrm{CRH}$ and band assignments.

\begin{tabular}{|c|c|}
\hline Wavenumber $\left(\mathrm{cm}^{-1}\right)$ & Band assignments and remarks \\
\hline 3405.67 (vs, b) & $\begin{array}{l}\text { O-H stretching (intermolecular H-bonded); } \mathrm{N}-\mathrm{H} \text { stretching (primary and } \\
\text { secondary amines); } \mathrm{N}-\mathrm{H} \text { of pyrrole and imide groups (all these bands are } \\
\text { probably overlapped into the big band observed between } 3000-3674 \mathrm{~cm}^{-1} \text { ) }\end{array}$ \\
\hline $2928.38(\mathrm{~s})$ & $\begin{array}{l}\mathrm{C}-\mathrm{H} \text { stretching }\left(-\mathrm{CH}_{2}-\text { or }-\mathrm{CH}_{3}\right)-\text { two bands are expected; in this case, it's } \\
\text { overlapped with another band at ca. } 2883.7 \mathrm{~cm}^{-1} ; \mathrm{O}-\mathrm{H} \text { stretching of }-\mathrm{COOH}\end{array}$ \\
\hline$\sim 2510(\mathrm{vw}, \mathrm{b})$ & S-H stretching \\
\hline $2361.41(\mathrm{w})$ & $\mathrm{C} \equiv \mathrm{N}$ stretching \\
\hline $1732(\mathrm{w})$ & $\mathrm{C}=\mathrm{O}$ stretching of saturated carboxyl(ate)ic acid \\
\hline $1642.09(\mathrm{~s})$ & $\mathrm{N}-\mathrm{H}$ bending; $\mathrm{C}=\mathrm{O}$ stretching; $\mathrm{O}-\mathrm{H}$ vibrations from glucoside units \\
\hline $1428.03(\mathrm{~m})$ & $-\mathrm{C}(=\mathrm{O})-\mathrm{O}^{-}$symmetric stretching \\
\hline $1372.1(\mathrm{~m})$ & $\mathrm{O}-\mathrm{H}$ bending \\
\hline $1245.79(\mathrm{vw})$ & $\mathrm{C}-\mathrm{O}$ stretching \\
\hline $1154.19(\mathrm{~s})$ & $\mathrm{C}-\mathrm{OH}$ stretching \\
\hline 1017.27 (vs) & $\begin{array}{l}\mathrm{C}=\mathrm{S} \text { stretching; } \mathrm{P}-\mathrm{O}-\mathrm{R} \text { stretching; (organo)phosphate stretching; inorganic } \\
\text { tribasic phosphates, } \mathrm{PO}_{4}^{3-}\end{array}$ \\
\hline $858.17(w)$ & Para-disubstituted benzene ring \\
\hline $763.67(w)$ & Monosubstituted phenyl ring \\
\hline $721(w)$ & $-\mathrm{CH}_{2}$ - rocking; monosubstituted phenyl ring \\
\hline
\end{tabular}

based on available literature [19]. It is very clear that functional groups like acid $(-\mathrm{COOH})$, amine (primary- $\mathrm{NH}_{2}$ and secondary-NHR), imine $(>\mathrm{C}=\mathrm{NH})$, alcohol (-OH), sulphydryl (-SH), mono-substituted and para-disubstituted benzene rings are available in $\mathrm{CRH}$. Availability of these functional groups supports chemisorption process. [20].

Based on the infrared spectral studies, a better depiction of the ability of $\mathrm{CRH}$ to coordinate with metal ions is provided in Figure 3. Coordination could be considered as a heterogeneous phenomenon where $\mathrm{CRH}$ acts as a solid phase while the aqueous phase contains metal ions. Equilibrium was set up between the two species at the solid-solution interface. The abstraction of metals from aqueous solution is simply the coordination of metal ions to active ligating sites of CRH. This correlates with the results from pseudo-second-order kinetics studies indicating chemisorption as the driving force for adsorption.

\subsubsection{UV-Visible Spectrophotometry}

The oxalate $\left(\mathrm{C}_{2} \mathrm{O}_{4}^{2-}, \mathrm{ox}\right)$ present in $\mathrm{CRH}$ as a secondary metabolite [21] could possibly interact with $\mathrm{M}(\mathrm{II})[\mathrm{M}=\mathrm{Cu}(\mathrm{II})$ and $\mathrm{Pb}$ (II)] in aqueous solutions to give rise to a coordination complex, $\left[\mathrm{M}(\mathrm{ox})_{2}\right]^{2-}$ which are sparingly soluble in water. This was further proven by recording UV-Visible spectrum (Figure 4) of clear brown solution obtained by filtering the $\mathrm{CRH}$ suspension. Presence of peaks in the ultraviolet region between $190-366 \mathrm{~nm}$ set as an evidence for the presence 


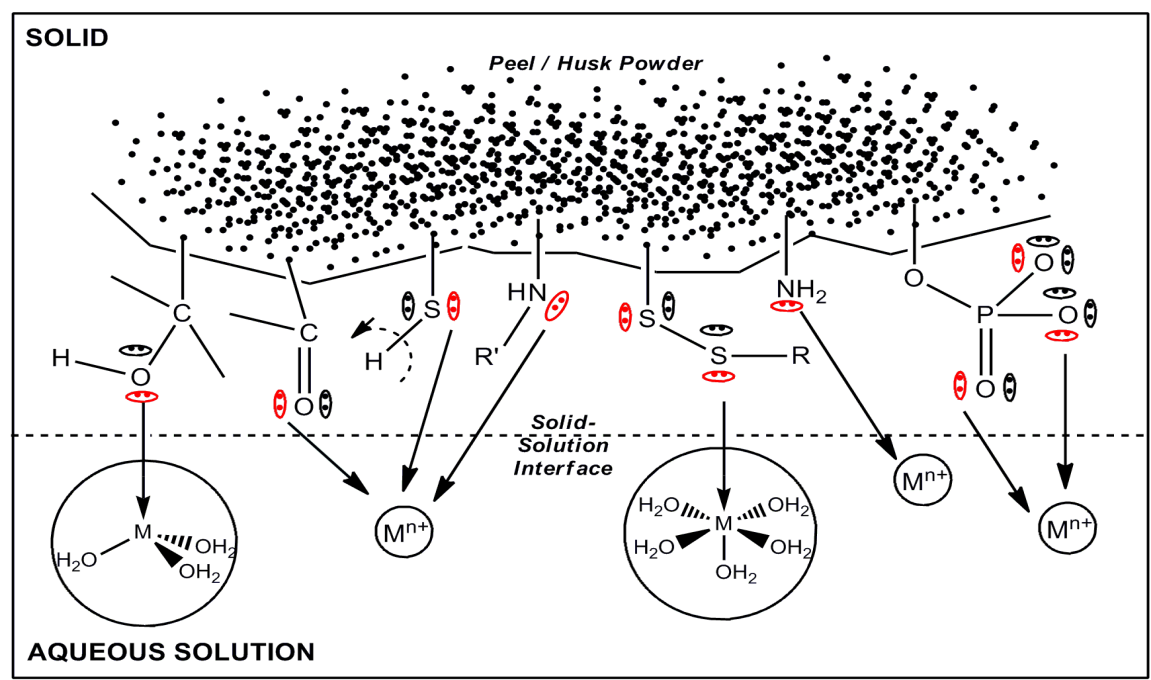

Figure 3. Possibilities of CRH functional groups to coordinate with metal ions [darkened portion: lone pairs of electrons for potential metal coordination].

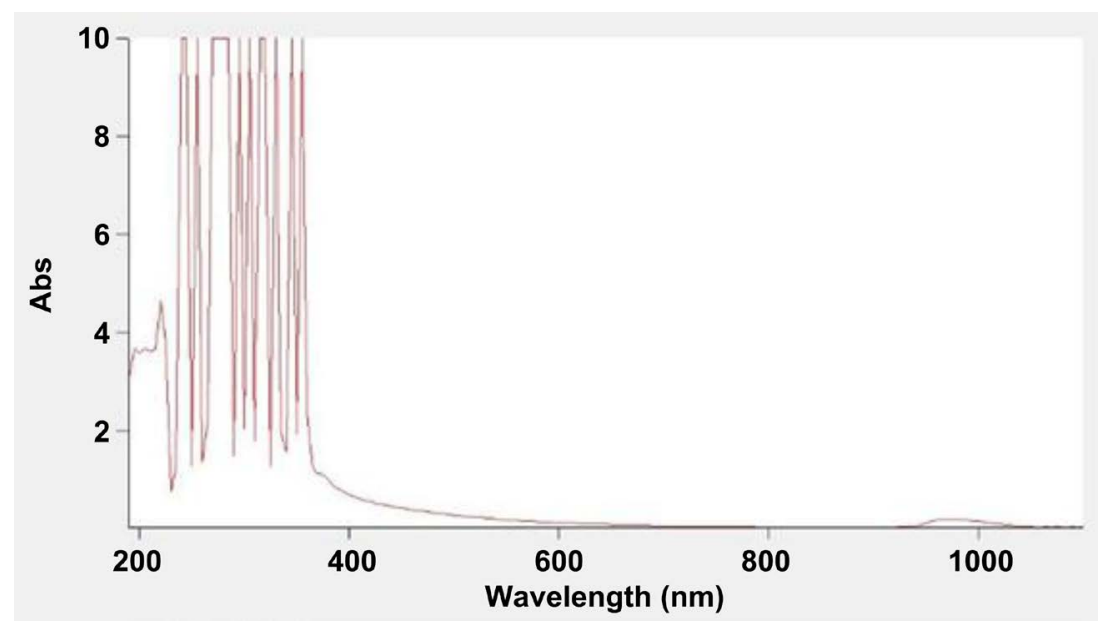

Figure 4. UV-Visible spectrum of clear solution obtained from CRH suspension.

of oxalate in the solution. Oxalates are characterized by two prominent absorptions at $190 \mathrm{~nm}$ due to $n \rightarrow \sigma^{\star}$ and $\sim 300 \mathrm{~nm}$ due to $n \rightarrow \pi^{\star}$ transitions [19]. Oxalate is a polydentate ligand (bidentate) which gives rise to stable chelates upon sequestering $\mathrm{M}(\mathrm{II})$ [22]. Because the complex was present in the filtrates which were subjected to ICP-OES analysis for metal estimations, some of the expected behaviors in the adsorption studies were not seen as reported by Jorgetto et al. [18].

\subsubsection{Elemental Analysis}

CHNSP analysis of CRH clearly supported the presence of sulphur, nitrogen and phosphorus containing groups which directly or indirectly aided in metal coordination. Table 2 provides a comparison of CHNSP data of the CRH from various studies. It can be concluded that the elemental compositions are variable, though they are all present in samples from various continents. 
Table 2. CHNSP data for CRH powder from various studies.

\begin{tabular}{cccc}
\hline Element & Lukuyu et al., 2014 & Jorgetto et al., 2014 & Present study (2021) \\
\hline Samples location & $\begin{array}{c}\text { Local market, } \\
\text { Ibadan city, } \\
\text { Oyo, Nigeria }\end{array}$ & $\begin{array}{c}\text { Conventional market, } \\
\text { Botucatu city, } \\
\text { Sao Paulo, Brazil }\end{array}$ & $\begin{array}{c}\text { Markham, Morobe, } \\
\text { Papua New Guinea }\end{array}$ \\
Continent & Africa & South America & Oceania (South Pacific) \\
Carbon (\%) & Not reported & 41.42 & 40.25 \\
Hydrogen (\%) & Not reported & 6.64 & 5.76 \\
Nitrogen (\%) & Not reported & 1.02 & 0.77 \\
Sulphur (\%) & 0.22 & 0.60 & 0.01 \\
Phosphorus (\%) & 0.14 & Not reported & 0.03 \\
$\{100-[$ C + H + N + S + P]\}\% & -- & 50.32 & 53.18 \\
(oxygen, minerals, etc.) & & &
\end{tabular}

\subsubsection{Surface Area and Pore Volume}

The BET surface area and the pore volume of CRH was found to be $0.9039 \mathrm{~m}^{2} / \mathrm{g}$ and $0.002101 \mathrm{~cm}^{3} / \mathrm{g}$ (based on single point adsorption on pores $<1019.662 \AA \mathrm{ra}$ dius) respectively. The result clearly corroborates with earlier findings and the surface area was found to be $<1 \mathrm{~m}^{2} / \mathrm{g}$ [18]. The data implies that the material is non-porous and hence rapid adsorption kinetics is expected which agreed well with the kinetic studies (Table 3).

\subsection{Adsorption Studies}

\subsubsection{Experimental Parameters}

The $\mathrm{pH}$ of the solution plays a very significant role in the adsorption process. For both $\mathrm{Cu}(\mathrm{II})$ and $\mathrm{Pb}(\mathrm{II})$, at lower $\mathrm{pH}$, the adsorption of both metals was found to be low (Figure 4). This could be due to the diminished exchange of acidic sites of $\mathrm{CRH}$ with metals on the basis of Le Chatelier principle. At low $\mathrm{pH}$, the hydrogen ion concentration is very high thus favoring the reverse reaction of Equation (6) and subsequently affecting the adsorption and removal processes of metal.

$$
\text { [polymer }]--\mathrm{H}+\mathrm{M}^{\mathrm{n}+} \stackrel{\mathrm{H}^{+}}{\longleftrightarrow}[\text { polymer }]--\mathrm{M}^{(\mathrm{n}-1)+}+\mathrm{H}^{+}
$$

Beyond $\mathrm{pH}$ 7, the adsorption decreases, probably due to metals precipitating as hydroxides (Equation (7)). The maximum adsorption of $\mathrm{Pb}$ (II) and $\mathrm{Cu}$ (II) occurs at around $\mathrm{pH} 4$ with removal of $95.26 \%$ and $78.66 \%$ respectively (Figure 4). However, the results are in contrast with the literature reported data [14] where the $\mathrm{Cu}(\mathrm{II})$ adsorption to cassava husk was found to be rapid from $\mathrm{pH} 1$ 3 , beyond which the adsorption stabilizes to a plateau.

$$
\left[\mathrm{M}\left(\mathrm{H}_{2} \mathrm{O}\right)_{\mathrm{n}}\right]^{2+} \stackrel{\mathrm{pH}>7}{\longrightarrow}\left[\mathrm{M}\left(\mathrm{H}_{2} \mathrm{O}\right)_{\mathrm{n}-2}(\mathrm{OH})_{2}\right] \downarrow+2 \mathrm{H}_{3} \mathrm{O}^{+}
$$

The effective dosage for $\mathrm{Pb}(\mathrm{II})$ was found to be $0.1 \mathrm{~g}$ of $\mathrm{CRH}$ in $100 \mathrm{~mL}$ of metal solution which adsorbed $95.2 \%$ (Figure 5). For $\mathrm{Cu}(\mathrm{II})$, the effective dosage was found to be $1 \mathrm{~g}$ in $100 \mathrm{~mL}$ of metal solution (78.98\% adsorption). This indicates 


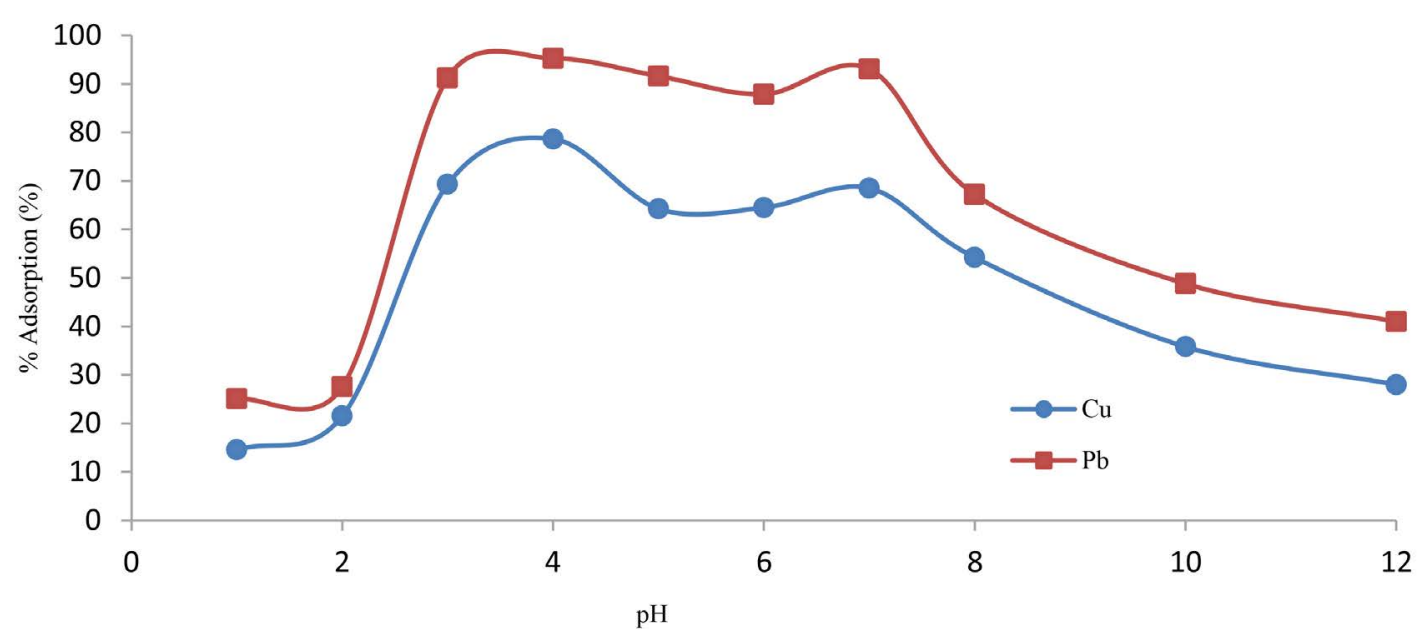

Figure 5. Effect of $\mathrm{pH}$ on the adsorption of $\mathrm{Pb}(\mathrm{II})$ and $\mathrm{Cu}(\mathrm{II})$ to $\mathrm{CRH}$.

Table 3. $\mathrm{pH}$, specific surface are and pore volume data for $\mathrm{CRH}$.

\begin{tabular}{cc}
\hline Parameter & Observed values \\
\hline $\mathrm{pH}$ (as solution) & 3.5 \\
Specific surface area (as powder) & $0.9039 \mathrm{~m}^{2} / \mathrm{g}$ \\
Pore volume (as powder) & $0.0021 \mathrm{~cm}^{3} / \mathrm{g}$ \\
\hline
\end{tabular}

that the nature of metal ion is very vital for adsorption process because higher dosage (10 times more for $\mathrm{Cu}(\mathrm{II})$ compared to that of $\mathrm{Pb}(\mathrm{II})$ ) as well as lower adsorption was observed for $\mathrm{Cu}(\mathrm{II})$.

The removal of $\mathrm{Cu}$ (II) and $\mathrm{Pb}$ (II) with $\mathrm{CRH}$ was fast (Figure 6). The adsorption equilibrium time for $\mathrm{Pb}(\mathrm{II})$ and $\mathrm{Cu}(\mathrm{II})$ was found to be 2 and 25 minutes respectively. The adsorption of both $\mathrm{Pb}(\mathrm{II})$ and $\mathrm{Cu}(\mathrm{II})$ onto $\mathrm{CRH}$ was high at lower concentration and decreases as the concentration increases (Figure 7). With $0.5 \mathrm{mg} / \mathrm{L}, \mathrm{Pb}$ (II) and $\mathrm{Cu}(\mathrm{II})$ adsorption was found to be $94 \%$ and $76 \%$ respectively. Effects of $\mathrm{pH}$, dosage, contact time and concentration on the adsorption of $\mathrm{Cu}(\mathrm{II})$ and $\mathrm{Pb}(\mathrm{II})$ ions to $\mathrm{CRH}$ are provided in Figures 5-8.

\subsubsection{Equilibrium Studies}

Table 4 below gives the concentration values (initial concentration, $C_{p}$ and equilibrium concentration, $q_{e}$ ) for $\mathrm{Cu}(\mathrm{II})$ and $\mathrm{Pb}(\mathrm{II})$ solutions which were used to plot the Langmuir and Freundlich Isotherms.

\section{1) Langmuir Isotherm}

Table 4 gives the values of $C_{i}$ and $q_{e}$ for the metals which were used to plot the isotherms. The Langmuir isotherm model for both metal ions is presented in Figure 9. The maximum adsorption capacities $\left(q_{\max }\right)$ for completely adsorbed metal monolayer coverage were found to be 26.74 and $16.50 \mathrm{mg} / \mathrm{g}$ of CRH for $\mathrm{Pb}$ (II) and $\mathrm{Cu}$ (II) ions respectively (Table 5 ). $K_{\text {ads }}$ is related to the affinity of the binding sites and lower values of $K_{a d s}[0.0652$ and 0.0175 for $\mathrm{Pb}$ (II) and $\mathrm{Cu}$ (II) respectively] indicated the particle radius for $\mathrm{CRH}$ was smaller towards adsorption 


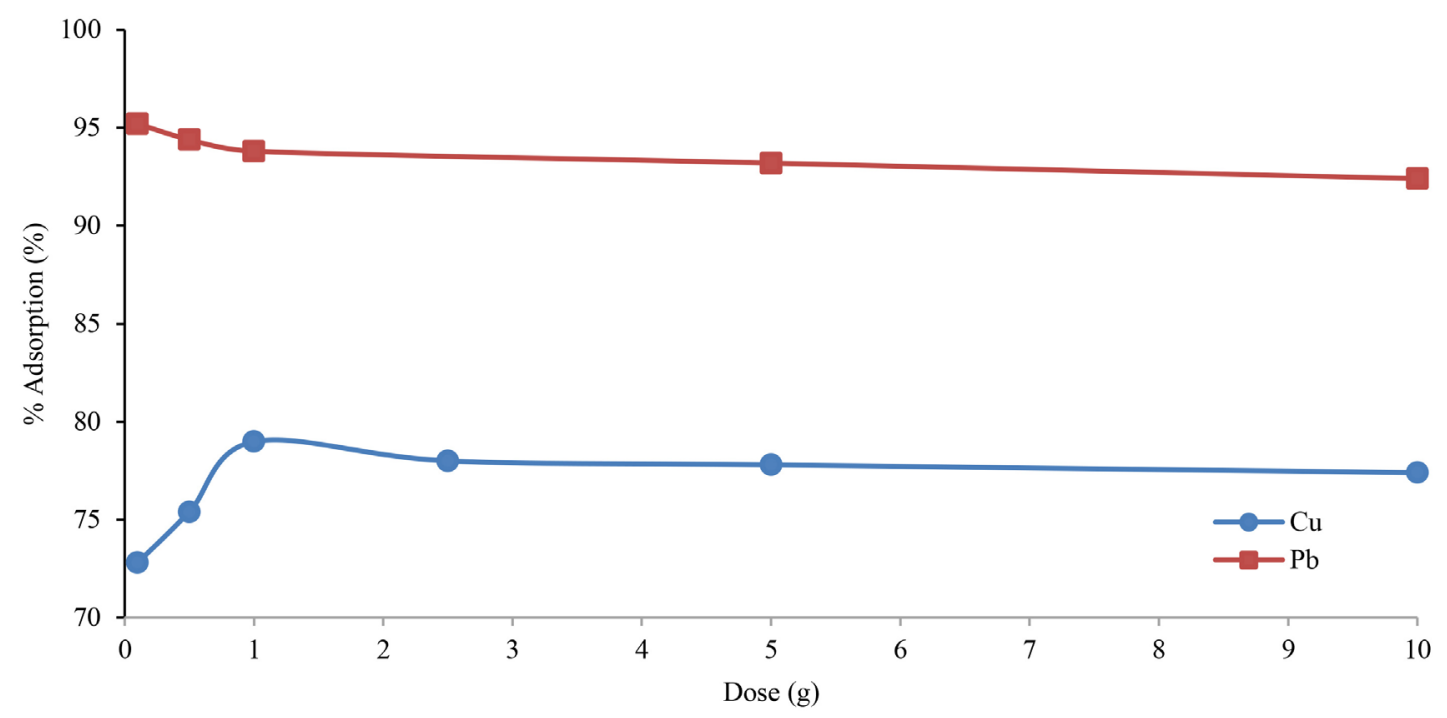

Figure 6. Effect of adsorbent dosage on the adsorption of $\mathrm{Pb}$ (II) and $\mathrm{Cu}(\mathrm{II})$ to $\mathrm{CRH}$.

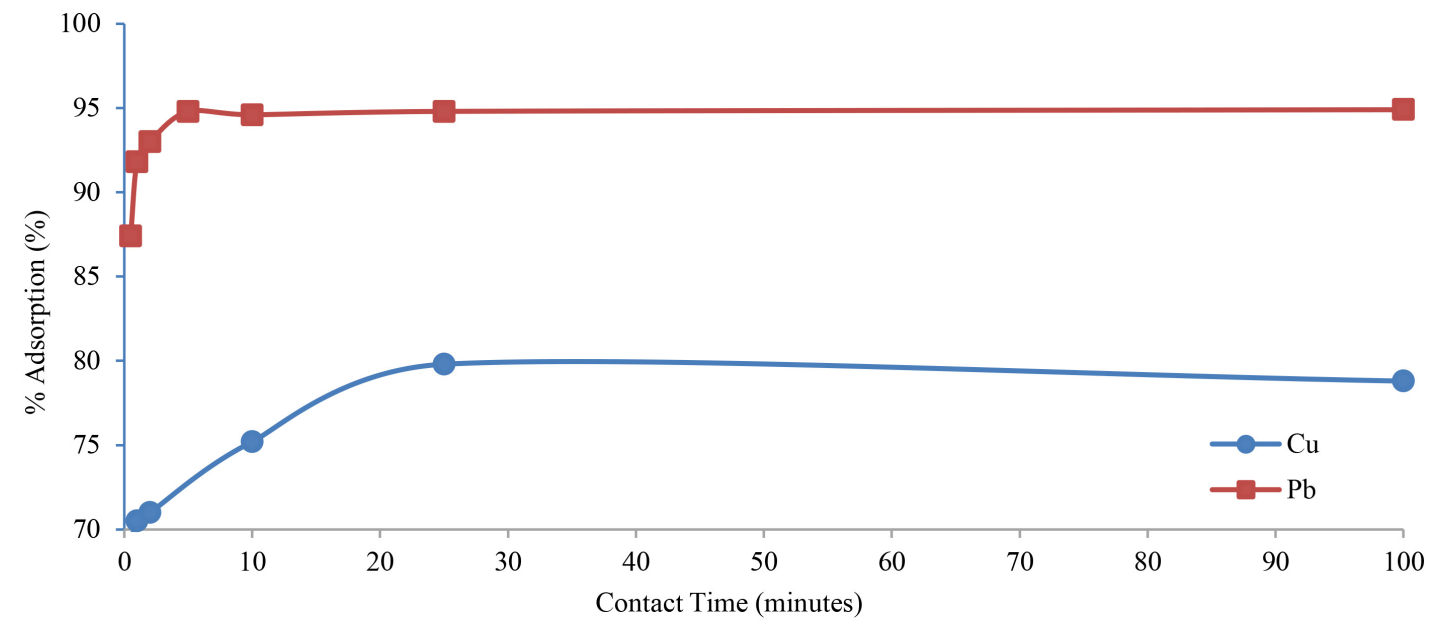

Figure 7. Effect of contact time on the adsorption of $\mathrm{Pb}$ (II) and $\mathrm{Cu}$ (II) to $\mathrm{CRH}$.

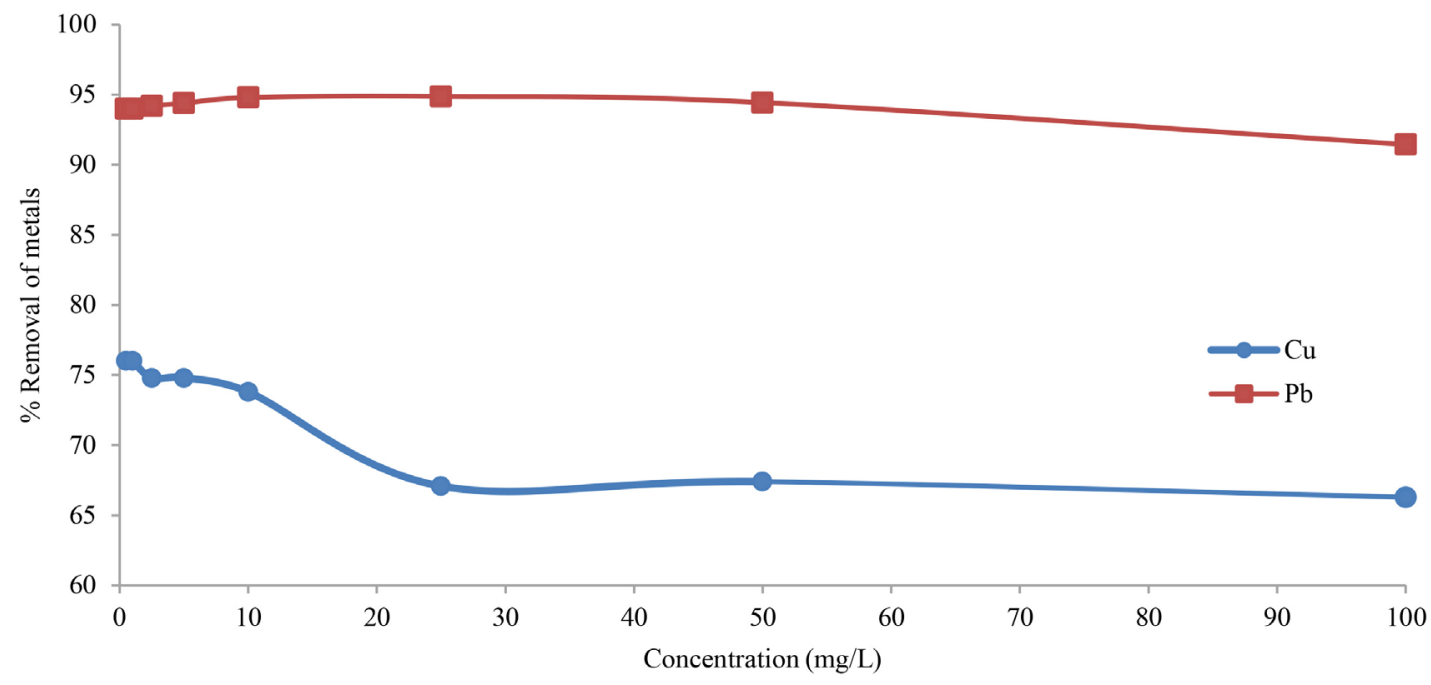

Figure 8. Effect of concentration on the adsorption of $\mathrm{Pb}$ (II) and $\mathrm{Cu}$ (II) to $\mathrm{CRH}$. 


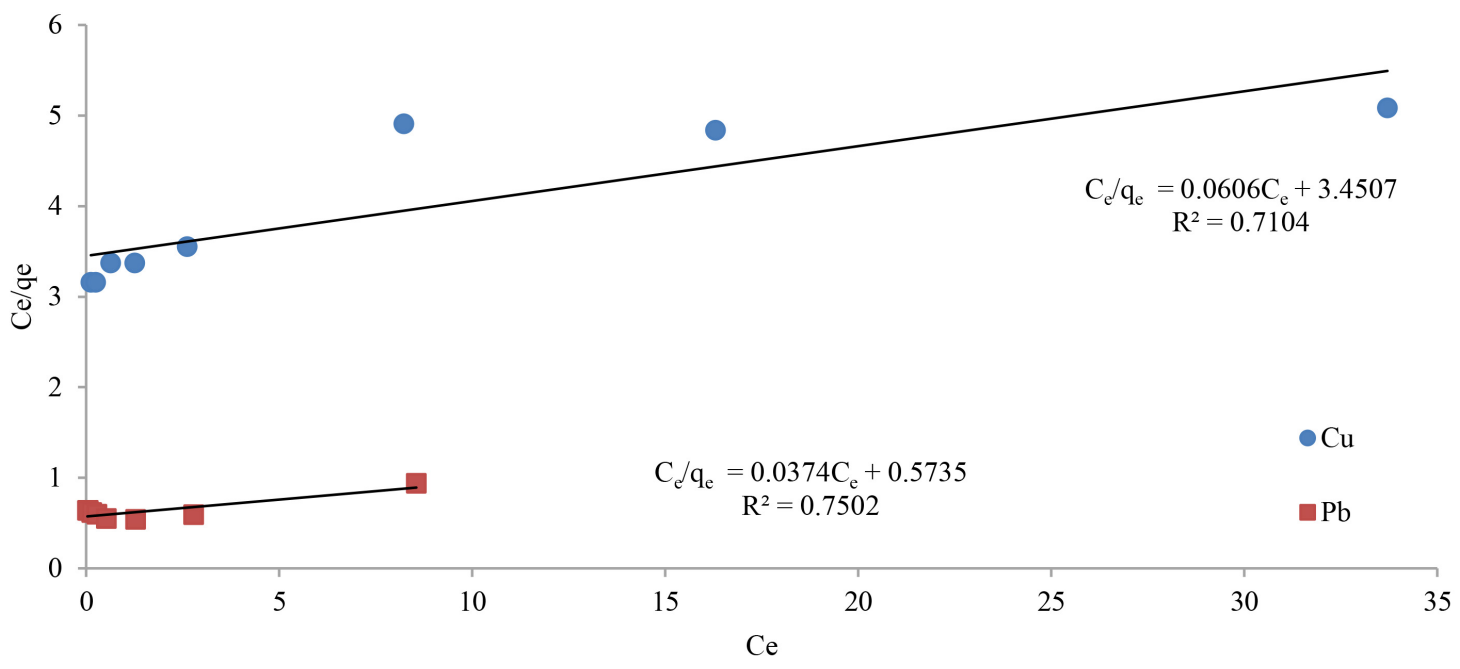

Figure 9. Langmuir isotherm for $\mathrm{Pb}$ (II) and $\mathrm{Cu}(\mathrm{II})$ adsorption to $\mathrm{CRH}$.

Table 4. Equilibrium values for $\mathrm{Pb}(\mathrm{II})$ and $\mathrm{Cu}(\mathrm{II})$ adsorption.

\begin{tabular}{ccccccccc}
\hline$C_{i}(\mathrm{mg} / \mathrm{L})$ & 0.5 & 1.0 & 2.5 & 5 & 10 & 25 & 50 & 100 \\
\hline$q_{e}(\mathrm{~Pb}(\mathrm{II}))$ & 0.047 & 0.094 & 0.235 & 0.472 & 0.948 & 2.372 & 4.722 & 9.145 \\
$q_{e}(\mathrm{Cu}(\mathrm{II}))$ & 0.038 & 0.076 & 0.187 & 0.374 & 0.738 & 1.677 & 3.37 & 6.629 \\
\hline
\end{tabular}

Table 5. Langmuir isotherm and its coefficients.

\begin{tabular}{cccccc}
\hline Metal & Equation & $\boldsymbol{q}_{\max }(\mathrm{mg} / \mathrm{g})$ & $\boldsymbol{K}_{\text {ads }}$ & $\boldsymbol{R}^{2}$ & $\boldsymbol{R}_{\boldsymbol{L}}$ \\
\hline $\mathrm{Pb}(\mathrm{II})$ & $C_{e} / q_{e}=0.0489 C_{e}+0.1273$ & 26.74 & 0.0652 & 0.75 & $<1$ \\
$\mathrm{Cu}(\mathrm{II})$ & $C_{e} / q_{e}=0.0546 C_{e}+3.4662$ & 16.50 & 0.0175 & 0.71 & $<1$ \\
\hline
\end{tabular}

[9]. The separation factors $\left(R_{L}\right)$ for both $\mathrm{Pb}(\mathrm{II})$ and $\mathrm{Cu}(\mathrm{II})$ adsorption to $\mathrm{CRH}$ lie very close to 1 (Table 6 ) which supported its low $R^{2}$ value for less favorable adsorption.

\section{2) Freundlich Isotherm}

The experimental data for $\mathrm{Pb}(\mathrm{II})$ and $\mathrm{Cu}(\mathrm{II})$ adsorption onto $\mathrm{CRH}$ showed a very good linear relationship with Freundlich isotherm model (Figure 10). This indicated that the adsorption reached equilibrium on a heterogeneous surface or the adsorption energies of $\mathrm{CRH}$ particles vary. Fitting the Freundlich isotherm also means the adsorption has multi layers of metals adsorbed onto CRH. As indicated in Table 7, the adsorption of $\mathrm{Pb}$ (II) and $\mathrm{Cu}(\mathrm{II})$ to $\mathrm{CRH}$ is favorable because it fulfills the condition of $n>1$ [18]. This data correlated the adsorption capacity, $K$ value which was found to be 1.5485 and $0.2780 \mathrm{mg} / \mathrm{g}$ for $\mathrm{Pb}$ (II) and $\mathrm{Cu}(\mathrm{II})$ respectively. A very good linear relationship has indicated the strong binding of $\mathrm{Pb}(\mathrm{II})$ and $\mathrm{Cu}(\mathrm{II})$ ions to $\mathrm{CRH}$ [23].

\subsubsection{Adsorption Kinetic Studies}

\section{1) Pseudo-First-Order Kinetics}

The experimental data for the adsorption of $\mathrm{Pb}(\mathrm{II})$ and $\mathrm{Cu}(\mathrm{II})$ did not fit well 
Table 6. Comparison of separation factors $\left(R_{L}\right)$ between $\mathrm{Pb}$ (II) and $\mathrm{Cu}$ (II) for adsorption with $\mathrm{CRH}$.

\begin{tabular}{ccc}
\hline$C_{i}$ & & $R_{L}$ \\
\cline { 2 - 3 } & $\mathrm{Pb}(\mathrm{II})$ & $\mathrm{Cu}(\mathrm{II})$ \\
\hline 0.5 & 0.839 & 0.992 \\
1.0 & 0.723 & 0.984 \\
2.5 & 0.510 & 0.961 \\
5.0 & 0.342 & 0.926 \\
10.0 & 0.207 & 0.862 \\
50.0 & 0.050 & 0.556 \\
100.0 & 0.025 & 0.385 \\
\hline
\end{tabular}

Table 7. Freundlich isotherm and its coefficients.

\begin{tabular}{ccccc}
\hline Metal ion & Equation & $\boldsymbol{K}(\mathrm{mg} / \mathrm{g})$ & $\boldsymbol{n}$ & $\boldsymbol{R}^{2}$ \\
\hline $\mathrm{Pb}(\mathrm{II})$ & $\log q_{e}=0.9673 \log C_{e}+0.1899$ & 1.54846 & 1.0338 & 0.99 \\
$\mathrm{Cu}(\mathrm{II})$ & $\log q_{e}=0.9022 \log C_{e}-0.556$ & 0.27797 & 1.1084 & 1.0 \\
\hline
\end{tabular}

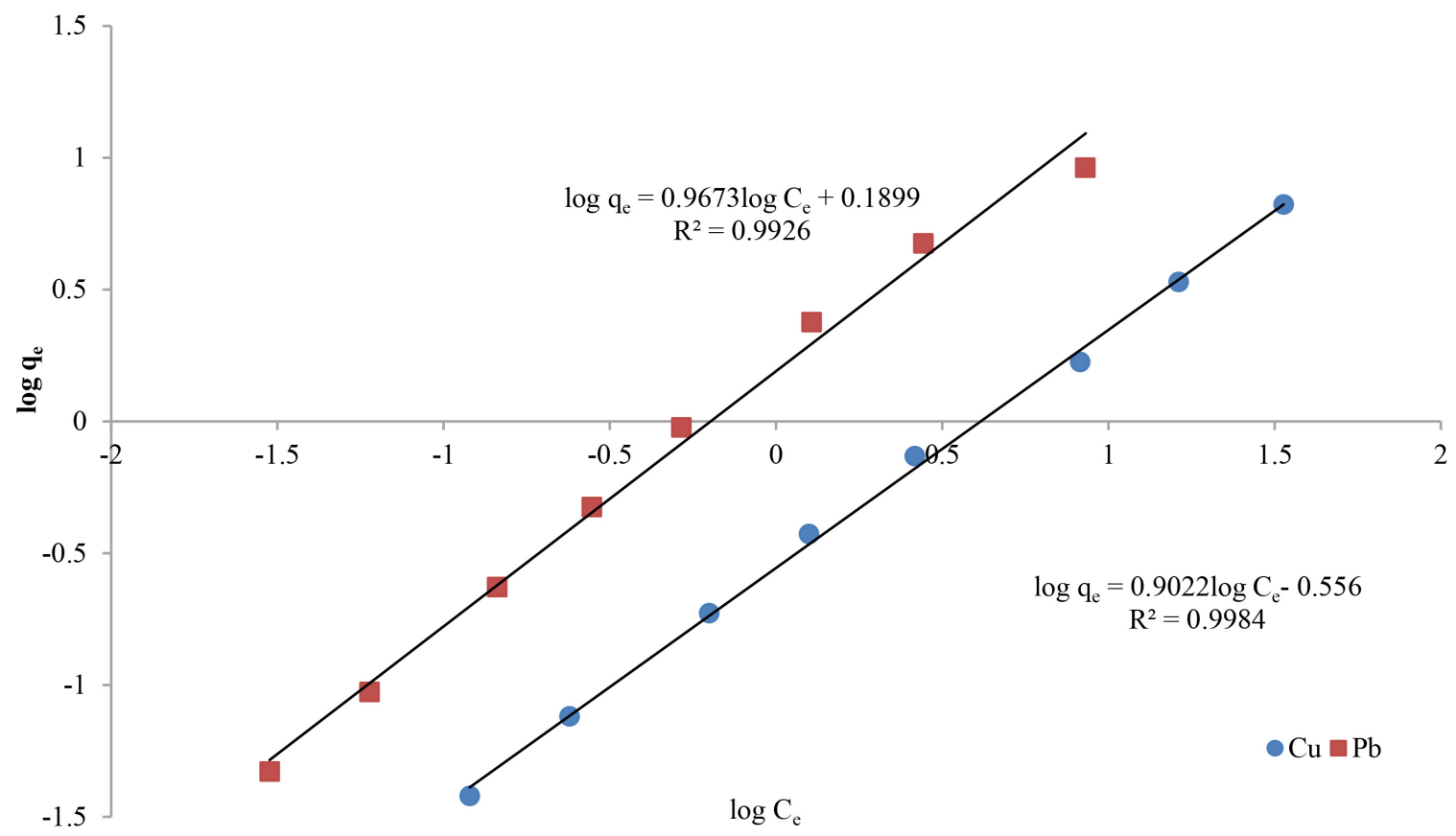

Figure 10. Freundlich isotherm for $\mathrm{Pb}(\mathrm{II})$ and $\mathrm{Cu}(\mathrm{II})$ adsorption to $\mathrm{CRH}$.

with Pseudo-first-order kinetic model $\left(R^{2}=0.2619\right.$ and 0.1993 respectively) as shown in Figure 11. No correlation was found for comparing the experimental equilibrium adsorption capacity $\left(q_{\text {e.exp }}\right)$ and calculated equilibrium adsorption capacity $\left(q_{\text {e.cal }}\right)$ (Table 8$)$. It can be concluded that the adsorption process did not follow pseudo first order model [23].

2) Pseudo-Second-Order Kinetics 


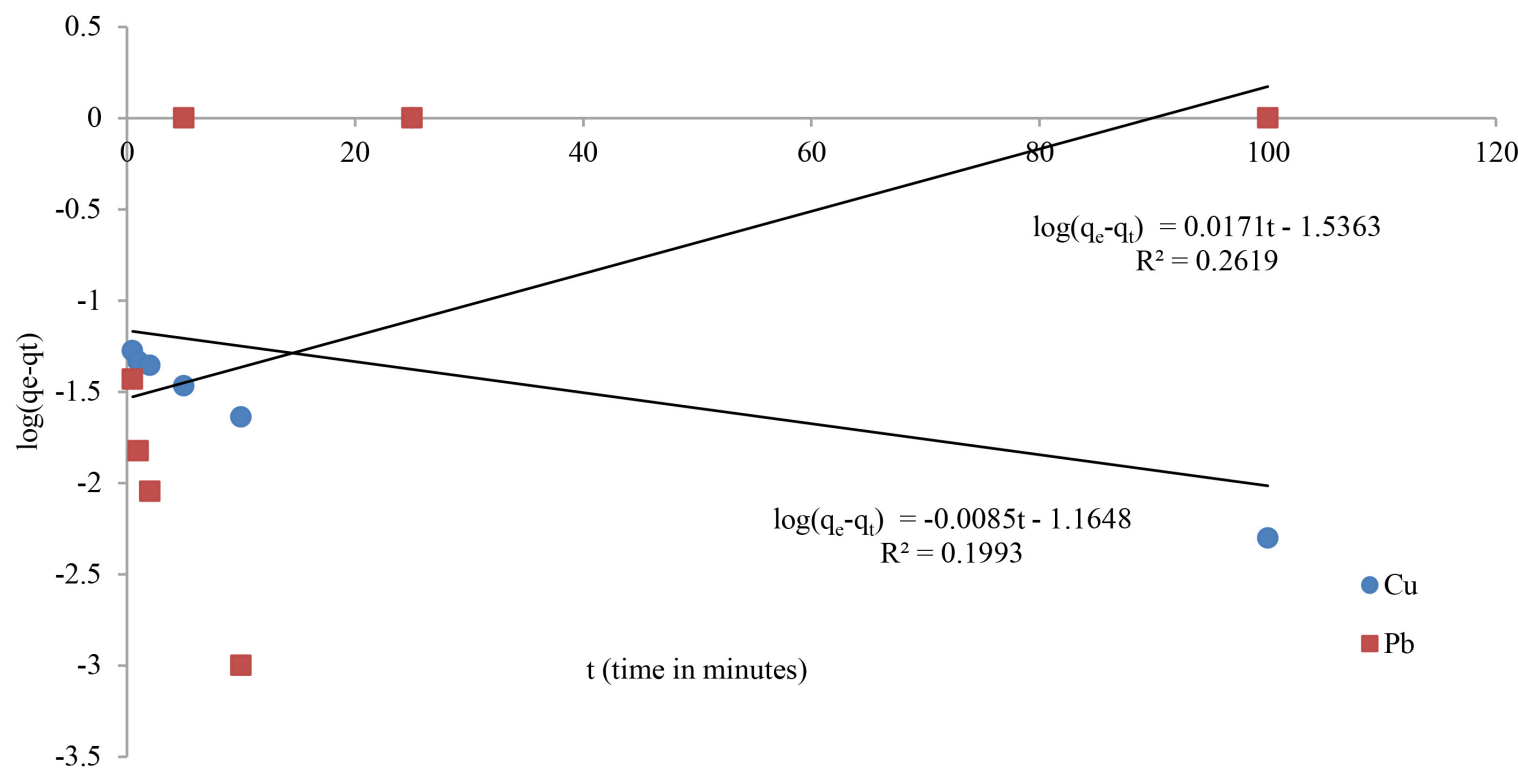

Figure 11. Pseudo-first-order kinetics for adsorption of $\mathrm{Pb}$ (II) and $\mathrm{Cu}$ (II) to $\mathrm{CRH}$.

Table 8. Pseudo-first-order kinetics coefficients for $\mathrm{Pb}$ (II) and $\mathrm{Cu}$ (II) adsorption to $\mathrm{CRH}$.

\begin{tabular}{cccccc}
\hline Metal & Equation & $\boldsymbol{q}_{e . \text { cal }}(\mathrm{mg} / \mathrm{g})$ & $\boldsymbol{q}_{e . \text { exp }}(\mathrm{mg} / \mathrm{g})$ & $K_{1}\left(\mathrm{~min}^{-1}\right)$ & $R^{2}$ \\
\hline $\mathrm{Pb}(\mathrm{II})$ & $\log \left(q_{e}-q_{t}\right)=0.0171 t-1.5363$ & 0.0418 & 0.474 & -0.0394 & 0.26 \\
$\mathrm{Cu}(\mathrm{II})$ & $\log \left(q_{e}-q_{t}\right)=-0.0085 t-1.1648$ & 0.0684 & 0.399 & 0.0196 & 0.20 \\
\hline
\end{tabular}

Both the adsorption of $\mathrm{Pb}$ (II) and $\mathrm{Cu}$ (II) to $\mathrm{CRH}$ has shown a very good linear relationship ( $R^{2}=1$ for both cases) with the pseudo-second-order kinetic model (Figure 12). Furthermore, $q_{e \text { exp }}$ agreed well with $q_{\text {e.cal }}$ for $\mathrm{Pb}$ (II) but not so well with $\mathrm{Cu}(\mathrm{II})$ adsorption (Table 9). This agreed data implies that the adsorption depends on both the adsorbent and adsorbate and the rate limiting step was chemisorption process, involving valency forces through sharing or exchange of electrons between the adsorbent and adsorbate [16]. The availability of functional groups on $\mathrm{CRH}$ (Figure 2) very well supports chemisorption of $\mathrm{Pb}(\mathrm{II})$ and $\mathrm{Cu}(\mathrm{II})$ through exchange or sharing of electrons.

\subsection{Molecular Modeling Studies}

A thorough literature search was undertaken to identify that there was no reported structure for CRH. Hence, data sets for 2600 unique protein sequences were screened to get a reasonable starting geometry for docking (coordination) studies. Molecular modelling studies were performed using Schrödinger software; a sophisticated chemical simulation software used in materials research [24]. However, cassava protein sequences were reported [25] in an overview of protein identification studies. These sequences were used as the starting point for the modelling studies. Vanderschuren et al. [26] identified over 2600 unique proteins in the cassava root and provided data sets for these proteins. These data sets were screened to get the best possible match against the protein data bank to 


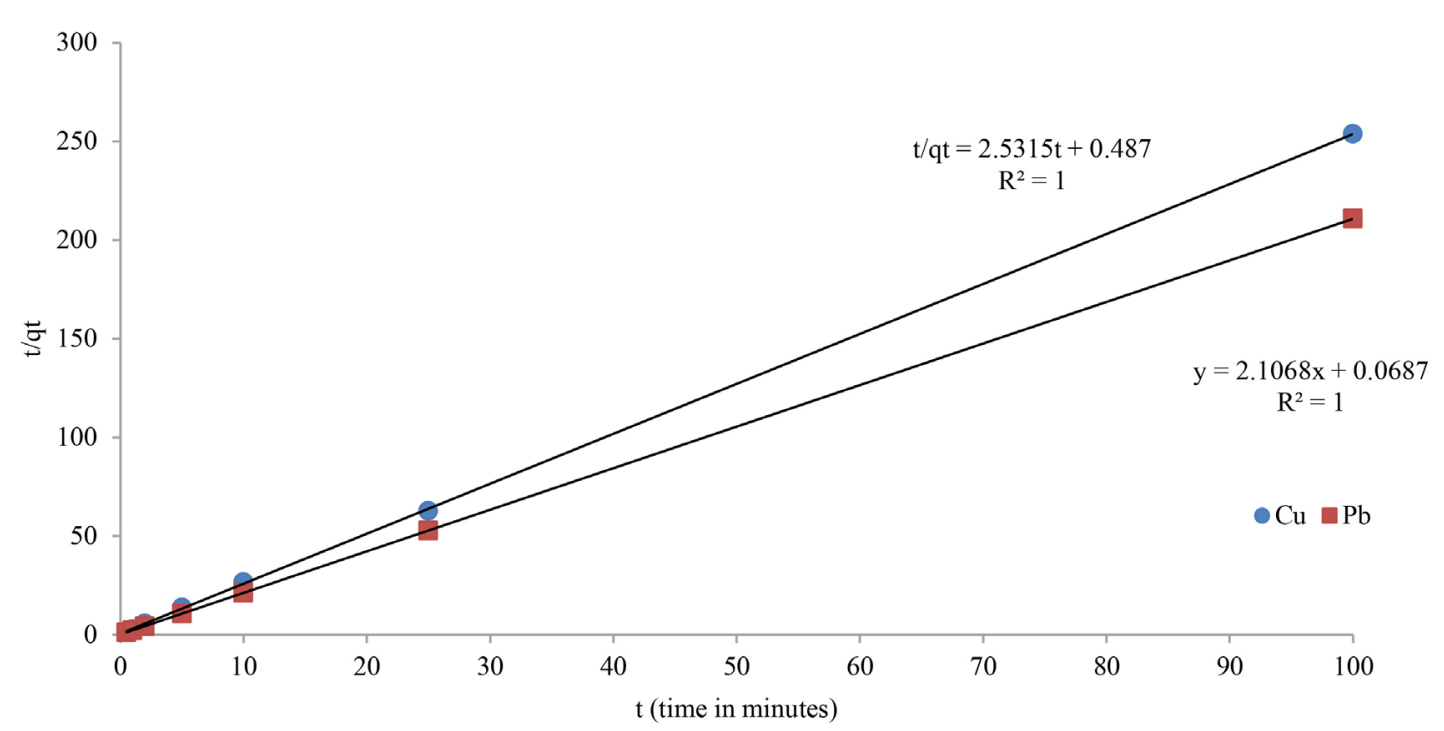

Figure 12. Pseudo second order kinetics for $\mathrm{Pb}(\mathrm{II})$ and $\mathrm{Cu}(\mathrm{II})$ adsorption to $\mathrm{CRH}$.

Table 9. Pseudo-second-order kinetic coefficients for adsorption of $\mathrm{Pb}$ (II) and $\mathrm{Cu}(\mathrm{II})$ to $\mathrm{CRH}$.

\begin{tabular}{|c|c|c|c|c|c|}
\hline Metal & Equation & $q_{e . c a l}(\mathrm{mg} / \mathrm{g})$ & $q_{e \cdot \exp }(\mathrm{mg} / \mathrm{g})$ & $K_{2}\left(\min ^{-1}\right)$ & $R^{2}$ \\
\hline $\mathrm{Pb}(\mathrm{II})$ & $\frac{t}{q_{t}}=2.1068 t+0.0687$ & 0.475 & 0.474 & 64.6085 & 1 \\
\hline $\mathrm{Cu}(\mathrm{II})$ & $\frac{t}{q_{t}}=2.5315 t+0.487$ & 0.395 & 0.495 & 4.5933 & 1 \\
\hline
\end{tabular}

get a reasonably good starting structure for our docking studies with metal ions. Docking studies using Glide predicted several sites in the structure capable of docking with metal ions (Figure 13).

\subsection{Coordination Ability of CRH to Metals}

The properties of metals that influence the coordination possibilities with the ligating atoms and hence the stability of coordination complex formed are 1) Nature; 2) Size, charge and charge density; 3) Electronic configuration; and 4) Hardness [27]. The properties of ligating atoms that decide the ease with which they coordinate with the metal are 1) Lonepair availability on the ligating atoms (N, O, S, etc.) and hence the basicity; and 2) Hardness of ligating atoms [27]. According to Pearson's hard and soft acids and bases (HSAB) concept [28], hard metals (hard Lewis acids) form stable complexes with hard ligating atoms (hard Lewis bases) and vice versa. According to $\mathrm{HSAB}$, both $\mathrm{Cu}(\mathrm{II})$ and $\mathrm{Pb}(\mathrm{II})$ ions could be classified as intermediate or borderline acids; similarly, $\mathrm{CN}^{-},>\mathrm{C}=\mathrm{O}, \mathrm{S}^{2-}$ and $\mathrm{RS}^{-}$are considered as soft bases while $\mathrm{O}^{2-},-\mathrm{NH}_{2}, \mathrm{PO}_{4}^{3-}$ and $-\mathrm{C}(\mathrm{O}) \mathrm{O}^{-}$are considered as hard bases [29]. However, considering the ionic radii of the two metals [ $\mathrm{Pb}$ (II) $119 \mathrm{pm}$ versus $\mathrm{Cu}$ (II) $73 \mathrm{pm}$ ], $\mathrm{Cu}$ (II) is smaller in size and hence easily polarizes the larger ligands compared to $\mathrm{Pb}$ (II). Thus $\mathrm{Pb}$ (II) could be relatively a softer Lewis acid compared to $\mathrm{Cu}(\mathrm{II})$, though both were originally grouped 


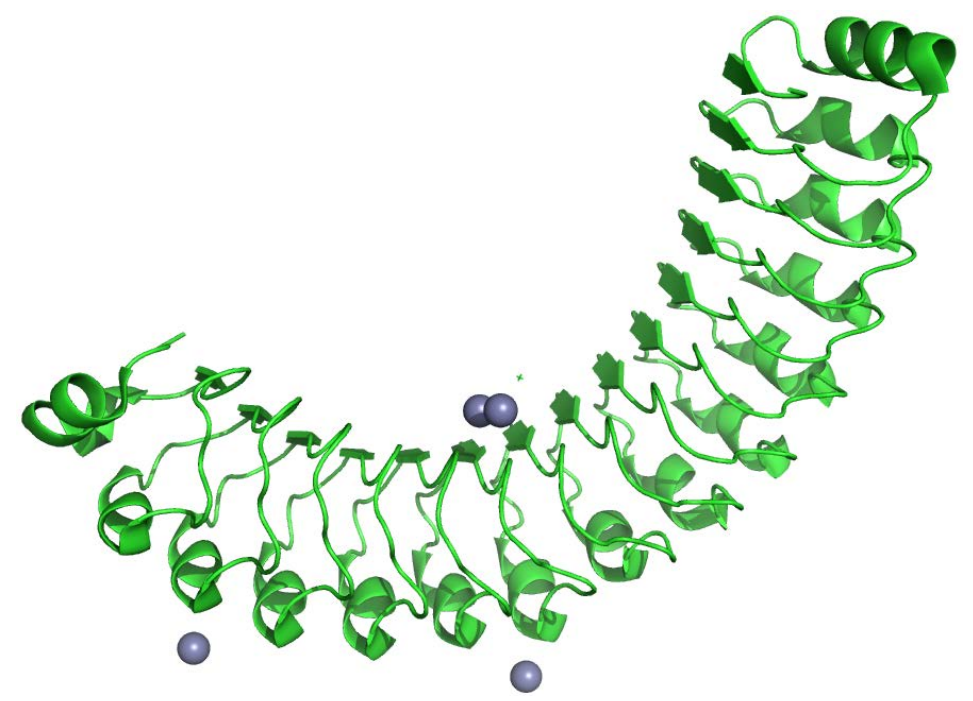

Figure 13. Structure of a model of cassava root husk docking with metal ions.

under borderline category. This electron polarization can possibly induce covalency on the bond formed, thus imparting stability to the species (coordinated complex) formed. The presence of varying ligating sites in $\mathrm{CRH}$ ensures that their coordination with both $\mathrm{Cu}(\mathrm{II})$ and $\mathrm{Pb}$ (II) occurs to differing extent based on aforesaid properties of ligands and metals. These facts were also supported by the molecular modeling studies.

\section{Conclusion}

The adsorption study was carried out using CRH powder by varying the parameters such as $\mathrm{pH}$, adsorbent dose, contact time, and concentration of metals. The study brought out the fact that this bioadsorbent was very effective in removing $\mathrm{Pb}(\mathrm{II})$ from aqueous solutions compared to $\mathrm{Cu}(\mathrm{II})$ ions and this was attributed to the soft nature of the former metal and the very high charge density of the latter. This research clearly has concluded that the metal removal processes by adsorption are very much dependent on the nature, surface charge density, and hardness of the metals, and the nature of sites available on the bioadsorbents for binding. This study has conducted trials pertaining to metal removal from aqueous solutions using naturally available bioadsorbents and correlates the results with the coordination ability of metals and the availability of ligating sites on bioadsorbents chosen. Attempts were made to assign FTIR spectral bands which also indirectly provide evidences for the presence of ubiquitous amounts and types of amino acids in the chosen bioadsorbent.

\section{Authors' Contributions}

Conceptualization, JG and KP; methodology, KP; formal analysis, KP.; investigation, KP, JG and RJ; resources, JG; data curation, KP and JG; writing-original draft preparation, KP; writing — review and editing, JG; visualization, JG, KP and RJ; supervision, JG; project administration, JG; funding acquisition, JG. All au- 
thors have read and agreed to the published version of this article.

\section{Funding}

This research was funded by Papua New Guinea University of Technology Research Funds.

\section{Acknowledgements}

KP thanks the Research Committee, PNGUoT for scholarship for pursuing M. Phil. Degree, Dr. Sivakumar Balakrishnan for guidance and generosity in editing this paper and Dr. Yalambing for approving the article processing charge. JG thanks the Research Committee, PNGUoT for the project funds. Dept. of Applied Sciences and Dept. of Agriculture, PNGUoT and SAIF, IITM are gratefully acknowledged for spectral data collected.

\section{Conflicts of Interest}

The authors confirm that the contents of this article have no conflict of interest.

\section{References}

[1] Council of Ethics, the Government Pension Fund-Global (2008) To the Ministry of Science, Recommendation of 14 August 2008.

[2] Papua New Guinea Constitutional Law Reform Commission (2013) Review of Environmental and Mining Laws Relating to Management and Disposal of Tailings. https://ramumine.wordpress.com/2012/11/06/papua-new-guinea-leads-the-world-i $\underline{\text { n-mine-pollution-of-waterways/ }}$

[3] Khraisheh, M., Al-Ghouti, M.A. and AlMomani, F. (2020) P. putida as Biosorbent for the Remediation of Cobalt and Phenol from Industrial Waste Wastewaters. Environmental Technology \& Innovation, 20, Article ID: 101148. https://doi.org/10.1016/j.eti.2020.101148

[4] Sulyman, M., Namiesnik, J. and Gierak, A. (2017) Low-Cost Adsorbents Derived from Agricultural By-Products/Wastes for Enhancing Contaminant Uptakes from Wastewater: A Review. Polish Journal of Environmental Studies, 26, 479-510. https://doi.org/10.15244/pjoes/66769

[5] Ruthven, D.M. (1984) Principles of Adsorption and Adsorption Process. John Wiley \& Sons Inc., Canada.

[6] McKay, G., Ed. (1996) Use of Adsorbents for the Removal of Pollutants from Wastewaters. CRC Press Inc., Florida.

[7] Egbosiuba, T.C., Abdulkareem, A.S., Roos, W.D., Afolabi, E.A., Tijani, J.O., Bankole, M.T., et al. (2021) Adsorption of $\mathrm{Cr}(\mathrm{VI}), \mathrm{Ni}(\mathrm{II}), \mathrm{Fe}(\mathrm{II})$ and $\mathrm{Cd}(\mathrm{II})$ Ions by KIAgNPs Decorated MWCNTs in a Batch and Fixed Bed Process. Scientific Reports, 11, Article No. 75. https://doi.org/10.1038/s41598-020-79857-Z

[8] Ibrahim, B. (2021) Heavy Metal Ions Removal from Wastewater Using Various Low-Cost Agricultural Wastes as Adsorbents: A Survey. Zanco Journal of Pure and Applied Sciences, 33, 76-91. https://doi.org/10.21271/ZJPAS.33.2.8

[9] Amar, M.B., Walha, K. and Salvado, V. (2021) Valorisation of Pine Cone as an Efficient Bioadsorbent for the Removal of $\mathrm{Pb}(\mathrm{II}), \mathrm{Cd}(\mathrm{II}), \mathrm{Cu}(\mathrm{II})$, and $\mathrm{Cr}(\mathrm{VI})$. Absorption Science and Technology, 2021, Article ID: 6678530. 
https://doi.org/10.1155/2021/6678530

[10] Information Technology Service (n.d.) Scientific Application-Schrodinger. The University of North Carolina, Chapel Hill.

https://its.unc.edu/research-computing/techdocs/scientific-application-schrodinger/

[11] Alene, A.N., Abate, G.Y., Habte, A.T. and Getahun, D.M. (2021) Utilization of a Novel Low-Cost Gibto (Lupinus albus) Seed Peel Waste for the Removal of Malachite Green Dye: Equilibrium, Kinetic, and Thermodynamic Studies. Journal of Chemistry, 2021, Article ID: 6618510. https://doi.org/10.1155/2021/6618510

[12] Banerjee, K., Ramesh, S.T., Gandhimathi, R., Nidheesh, P.V. and Bharathim, K.S. (2012) A Novel Agricultural Waste Adsorbent, Watermelon Shell for the Removal of Copper from Aqueous Solutions. Iranica Journal of Energy \& Environment, 3 , 143-156.

[13] Hossain, M.A., Ngo, H.H., Guo, W.S. and Nguyen, T.V. (2012) Biosorption of $\mathrm{Cu}(\mathrm{II})$ from Water by Banana Peel Based Biosorbent: Experiments and Models of Adsorption and Desorption. Journal of Water Sustainability, 2, 87-104.

[14] Berrazoum, A., Marouf, R., Ouadjenia, F. and Schott, J. (2015) Bioadsorption of a Reactive Dye from Aqueous Solution by Municipal Solid Waste. Biotechnology Reports, 7, 44-50. https://doi.org/10.1016/j.btre.2015.04.005

[15] Ezeonuegbua, B.A., Machidoa, D.A., Whonga, C.M.Z., Japhet, W.S. Alexiouc, A., Elazab, S.T., Qusty, N., Yaro, C.A. and Batihag, G.E.S. (2021) Agricultural Waste of Sugarcane Bagasse as Efficient Adsorbent for Lead and Nickel Removal from Untreated Wastewater: Biosorption, Equilibrium Isotherms, Kinetics and Desorption Studies. Biotechnology Reports, 30, Article No. e00614.

https://doi.org/10.1016/j.btre.2021.e00614

[16] Ho, Y.S. and McKay, G. (1999) Pseudo-Second Order Model for Sorption Processes. Process Biochemistry, 34, 451-465. https://doi.org/10.1016/S0032-9592(98)00112-5

[17] Ngah, W.S. and Hanafiah, M.A.K.M. (2008) Removal of Heavy Metal Ions from Wastewater by Chemically Modified Plant Wastes as Adsorbents: A Review. Bioresource Technology, 99, 3935-3948. https://doi.org/10.1016/j.biortech.2007.06.011

[18] Jorgetto, A.O., Silva, R.I.V., Saeki, M.J., Barbosa, R.C., Martines, M.A.U., Jorge, S.M.A., Silva, A.C.P., Schneidr, J.F. and Castro, G.R. (2014) Cassava Root Husks Powder as Green Adsorbent for the Removal of $\mathrm{Cu}(\mathrm{II})$ from Natural River Water. Applied Surface Science, 288, 356-362. https://doi.org/10.1016/j.apsusc.2013.10.032

[19] Williams, D.H. and Fleming, I. (1995) Spectroscopic Methods in Organic Chemistry. 5th Edition, McGraw Hill Publishing Company, Berkshire.

[20] Enrique Torres. Bioadsorption. (2020) A Review of the Latest Advances. Processes, 8, Article No. 1584. https://doi.org/10.3390/pr8121584

[21] Lukuyu, B., Okike, I., Duncan, A., Beveridge, M. and Blummel, M. (2014) Use of Cassava in Livestock and Aquaculture Feeding Programs. ILRI Discussion Paper 25, International Livestock Research Institute, Nairobi, 1-83.

[22] Greenwood, N.N. and Earnshaw, A. (1997) Chemistry of the Elements. Butterworth and Heinemann, Oxford.

[23] Krishna, D. and Sree, R.P. (2013) Removal of Chromium from Aqueous Solution by Custard Apple Peel Powder as Adsorbent. International Journal of Applied Science and Engineering, 11, 171-194.

[24] Schrödinger (2019) Schrödinger Release 2019-4: Glide. LLC, New York.

[25] Batista de Souza, C.R., Dos Reis, S.P. and Carvalho, L.J.C.B. (2015) An Overview of Protein Identification Studies in Cassava. Current Protein and Peptide Science, 16, 
219-227. https://doi.org/10.2174/1389203716666150224145407

[26] Vanderschuren, H., Nyaboga, E., Poon, J.S., Baerenfaller, K., Grossmann, J., HirschHoffmann, M., Kirchgessner, N., Nanni, P. and Gruisse, W. (2014) Large-Scale Proteomics of the Cassava Storage Root and Identification of a Target Gene to Reduce Postharvest Deterioration. Plant Cell, 26, 1913-1924. https://doi.org/10.1105/tpc.114.123927

[27] Cotton, F.A. and Wilkinson, G. (1988) Advanced Inorganic Chemistry. 5th Edition, John Wiley \& Sons Inc., Hoboken.

[28] Pearson, R.G. (1963) Hard and Soft Acids and Bases. Journal of American Chemical Society, 85, 3533-3539. https://doi.org/10.1021/ja00905a001

[29] Housecroft, C.E. and Sharpe, A.G. (2012) Inorganic Chemistry. 4th Edition, Pearson Education Limited, London. 